INDEPENDENT JOURNAL OF MANAGEMENT \& PRODUCTION (IJM\&P)

http://www.ijmp.jor.br

v. 12, n. 8, November-December 2021

ISSN: 2236-269X

DOI: 10.14807/ijmp.v12i8.1470

\title{
THE IMPACT OF CORRUPTION ON THE ECONOMIC GROWTH IN BANGLADESH, INDIA AND PAKISTAN: AN ARDL APPROACH
}

\author{
Md. Mamun Miah \\ Comilla University, Bangladesh \\ E-mail: mamunmiah2033@gmail.com \\ Tahmina Akter Ratna \\ Comilla University, Bangladesh \\ E-mail: tahminaratna2015@gmail.com \\ Shapan Chandra Majumder \\ Comilla University, Bangladesh \\ E-mail:scmajumder_71@yahoo.com \\ Submission: 10/20/2020 \\ Revision: $11 / 17 / 2020$ \\ Accept: 12/15/2020
}

\section{ABSTRACT}

Purpose of the study: Main purpose of the paper is to find out the impact of corruption on the economic growth of Bangladesh, India, and Pakistan. At the same time, our other objectives are to find the long and short-run effects of corruption on growth in these countries.

Methodology: For conducting the study, we have taken the data from Bangladesh, India, and Pakistan. For this study necessary secondary data have been collected from 1990 to 2016 based on countries like Bangladesh, India, and Pakistan. Data for economic growth (dependent) and trade (independent) are collected from World Development Bank and data for corruption are taken from International Country Risk published by the PRS Group. The study has used ECM ARDL Model and the Fixed Effect Model.

Findings: The result of the fixed effect model shows a 1percent increase in corruption decreases GDP by 0.07 units and shows a negative relationship with economic growth. Again if trade increases by 1 percent then growth will increase by 0.09 units on average and shows a positive relationship with economic growth. ECM ARDL Model shows the positive coefficient of corruption but not significant but trade has a long-run positive influence on economic growth. The error correction term indicating that the adjustment is corrected by $70 \%$ in these three countries. 
DOI: $10.14807 /$ ijmp.v12i8.1470

Contributions: This paper may be helpful for existing literature gap and also for further research. It will be helpful for policy makers to control corruption in three countries.

Keywords: Economic Growth, Corruption, Trade, Fixed Effect, Panel ARDL

\section{INTRODUCTION}

Mainly from the Latin word, we get "Corruption" which meaning is the decay of ethics, ill behavior, lack of morality, etc. Sometimes some people are bestowed with a higher position and they tried to involve in criminal activity to get contraband advantage or violation of power for one's private gain, which is regarded as corruption. All scales of development and on the progress of humankind, corruption is considered as an existing problem because of its antithetical impact. Not only powerful people are abusing power, but corruption also exists in every sector from the highest to the lowest level.

In the 2018 Corruption Perceptions Index reported by Transparency International, out of 175 countries, the position of Bangladesh is 149, which signified that Bangladesh is the least corrupt nation. Generally, the reasons for the corruption are a range of discretion; conflict; collusion between main decision-makers; enforcement of inadequate rules and regulations, laws, poor institutional capacities, lack of transparency, promotions, postings and transfers, lack of monitoring and control mechanism (Iftekharuzzaman, 2011).

Table 1 shows the GDP per capita of Bangladesh, India, and Pakistan. From the figure we see that GDP per capita is comparatively higher in India, then Pakistan, and lower in Bangladesh from the year 2010 to 2017.

Table 1: GDP per capita (constant 2010 US\$) from 2010 to 2017

\begin{tabular}{|c|c|c|c|}
\hline Year & $\begin{array}{c}\text { GDP per capita in } \\
\text { Bangladesh }\end{array}$ & $\begin{array}{c}\text { GDP per capita } \\
\text { in India }\end{array}$ & $\begin{array}{c}\text { GDP per capita in } \\
\text { Pakistan }\end{array}$ \\
\hline 2010 & 757.67 & 1345.77 & 987.41 \\
\hline 2011 & 797.41 & 1416.40 & 992.88 \\
\hline 2012 & 839.51 & 1474.97 & 1006.07 \\
\hline 2013 & 879.58 & 1550.14 & 1028.44 \\
\hline 2014 & 922.16 & 1645.33 & 1054.23 \\
\hline 2015 & 971.64 & 1758.84 & 1081.29 \\
\hline 2016 & 1029.58 & 1862.43 & 1117.52 \\
\hline 2017 & 1093.05 & 1963.55 & 1155.36 \\
\hline
\end{tabular}

$$
\text { Source: WDI, WB (2017) }
$$

Politicians and industrialists who are extremely corrupt, are playing a major role through providing false, wrong information, and news to the general public and they tried to control the Indian media. According to CPI in 2018, out of 180 countries, India ranked $78^{\text {th }}$ place which showed the declining procedure is steady in the perception of corruption. 
ISSN: 2236-269X

DOI: $10.14807 /$ ijmp.v12i8.1470

According to the 2018 Corruption perception Index, out of 175 countries, Pakistan is the 117 least corrupt nations, which is reported by Transparency International.

From 1995-2008, Pakistan averaged a corruption rank is 109.04. Pakistan is completely spoiled by corruption and is resulting in rising poverty, decreasing employment, hunger and is tarnished the image of the country, in which anticorruption has unfavorably failed to reduce the ongoing dishonesty and frauds. Figure 1 depict the trend of the corruption of Bangladesh, India, and Pakistan from 2005 to 2016. Compare to these three countries Bangladesh has higher corruption than India and Pakistan. Figure 1also reveals that India is in the second position of corruption among these three countries.

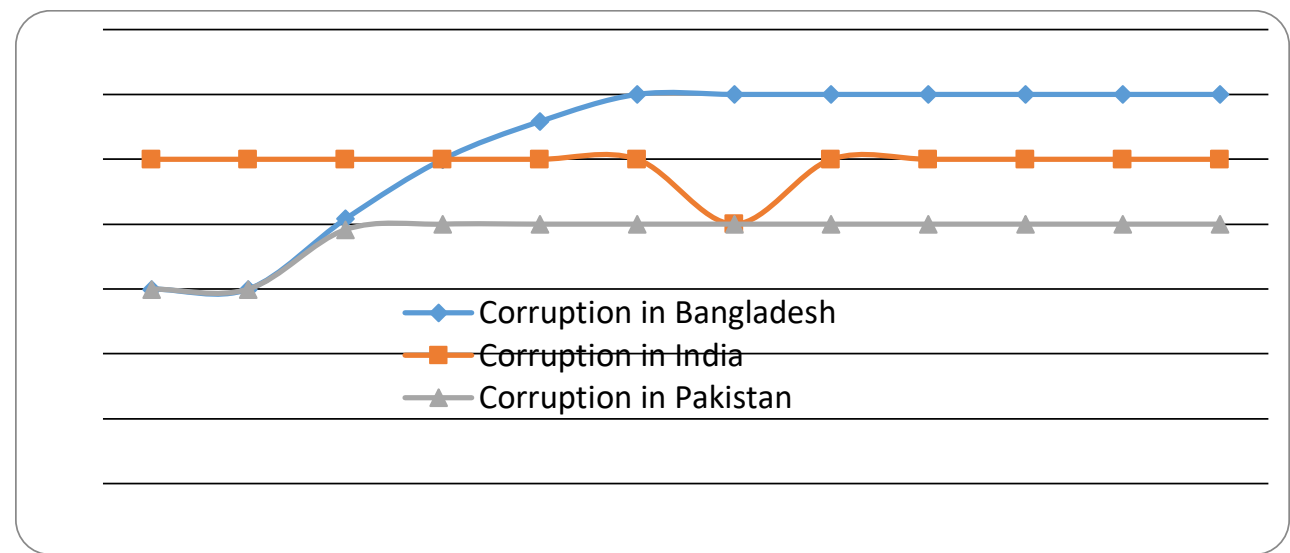

Figure 1: Trend of corruption in Bangladesh, India, and Pakistan from 2005 to 2016 Source: WB (2017)

Table 2 depicts the government effectiveness from 2015 to 2019 for Bangladesh, India and Pakistan collected from WGI, 2020. Negative value of government effectiveness indicates that Bangladesh and Pakistan have weak level of government effectiveness and India has comparatively well government effectiveness than Bangladesh and Pakistan; whereas the weak and strong government effectiveness ranges from -2.5 to 2.5 .

Table 2: Government Effectiveness from 2015 to 2019.

\begin{tabular}{|c|c|c|c|c|c|}
\hline \multicolumn{7}{|c|}{ Government Effectiveness } \\
\hline Country & 2015 & 2016 & 2017 & 2018 & 2019 \\
\hline Bangladesh & -0.72 & -0.68 & -0.73 & -0.75 & -0.74 \\
\hline India & 0.09 & 0.08 & 0.09 & 0.28 & 0.17 \\
\hline Pakistan & -0.67 & -0.65 & -0.60 & -0.63 & -0.68 \\
\hline
\end{tabular}

Source: Worldwide Governance Indicator (WGI), 2020.

Trade (\% of GDP) was also included in this study as independent variables to find the impacts of corruption on it. Figure 2 below shows the trend of trade in these selected three countries. 
DOI: 10.14807/ijmp.v12i8.1470

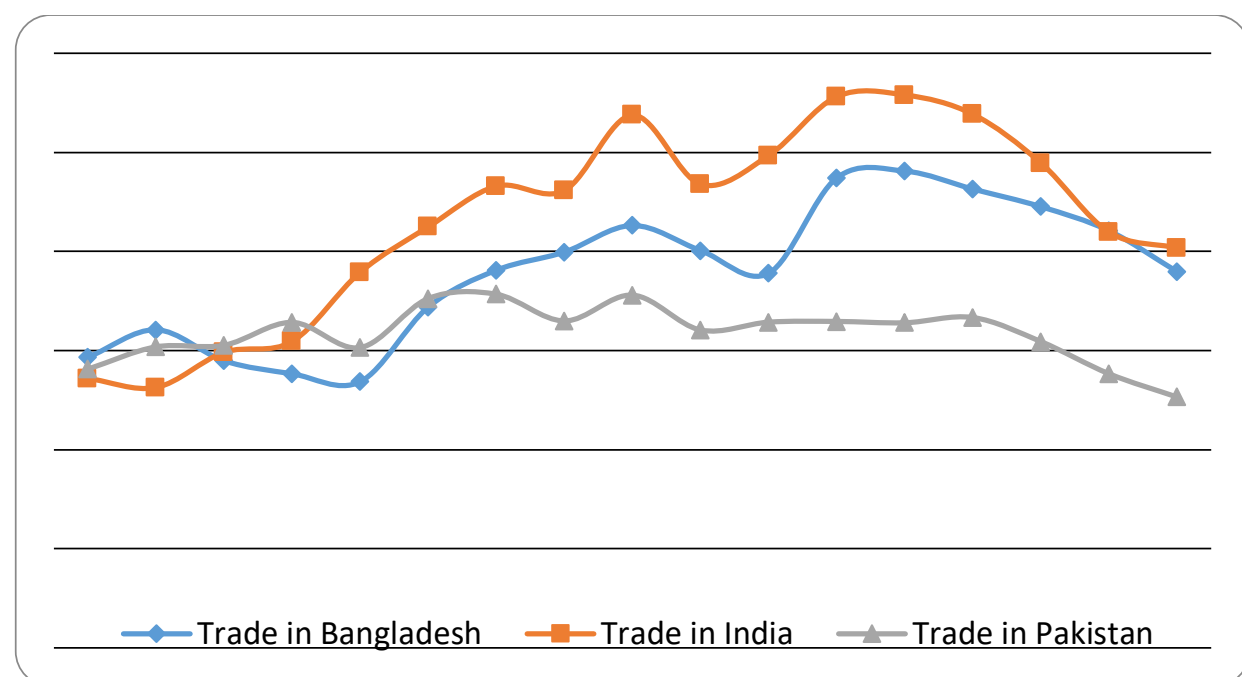

Figure 2: Trend of Trade in Bangladesh, India and Pakistan (\% of GDP) Source: WB (2017)

There are several research on this topic including both panel and time series analysis. We also investigate the impact of corruption on growth for three countries like Bangladesh, India, and Pakistan with the period 1990-2016 by using ECM ARDL Model and Fixed effect model.

\subsection{Objectives of the Study}

We have one main objective, which is to find corruption's impact on the economic growth of three South Asian countries (Bangladesh, India, and Pakistan). At the same time, our other objectives are to explore the long and short-run impact of corruption on growth in these countries.

\subsection{Significance of the Study}

To achieve certain personal goals and desires in dishonest or illegal ways, when people are trying to misuse their power with the help of money or some other way, then it is known as corruption. It is regarded as a constraint on development and growth. In this paper, one can able to know how the impact pattern of corruption among the three countries of Bangladesh, India, and Pakistan.

Corruptions have a direct impact on growth among these three countries. Here, it is also shown that other variable trade is indirectly impacted by corruption. Through this paper, we get to know the direct and indirect impact of corruption among these three countries is positive or negative. Moreover, it will also be acknowledged that corruption has long-run effects or not. With the help of this, the authority among these countries can think about it for anti-corruption.

In the study, the literature review is showed in part 2. Part 3 and 4 show methodology 
ISSN: 2236-269X

DOI: 10.14807/ijmp.v12i8.1470

and result discussion. Finally part 5 shows conclusion of the paper.

\section{LITERATURE REVIEW}

There are several studies including panel and time-series data analyses on this regard of corruption's impact on growth, some of these are summarized below.

Amin (2013) concludes corruption decreases the economic growth of Pakistan as corruption and economic growth has inverse relation in Pakistan and reduces the effectiveness of investment. Pulok (2012) shows in his paper the direct and indirect consequences on economic development, moreover the co-integration between them by the period of 1984-2008. He said economic growth in Bangladesh is adversely affected by corruption. In his paper, he showed that when corruption increases by $1 \%$, it has an effect on GDP and causes a reduction of $10 \%$ per capita GDP.

Obamuyi and Olayiwola (2019), investigate corruption as an obstruction to growth in Nigeria and India for the period of 1980-2015. They also have some findings in which they believe corruption has a positive role in development. Based on 19 Asian countries, Thach et al. (2017) analyze that corruption negatively affect on growth but they also mentioned its positive impacts.

Their paper used data from 19 Asian countries from 2004 to 2015. For this reason, they used data from 2004-2015 of those countries and examined D-GMM and quantile regression. In Nigeria, corruption and growth have a causal relationship, Egunjobi (2013) show the direction by using data from 1980-2009. They can reveal that the rate of foreign private investment declined and educational expenditure also reduced due to corruption, at the same time it raises the capital expenditure.

Economic growth and corruption have a causal relationship between them that as shown by Wright and Craigwell (2013) in their paper. Based on 42 developing countries, they proved their analysis with the help of linear as well as non-linear panel data. For doing this whole, they used data from the period of 1998-2009 of those countries.

The economic growth of ECO member countries is impacted by administrative corruption. But in this paper, Afghanistan, Iraq, and Iran were not involved. Based on the panel data approach from 2003 to 2008 the paper of Taghavi et al. (2013) shows that administrative corruption and growth have reversed and significant effects. Mustapha (2014) investigates 20 countries and able to find out that, those countries' GDP per capita is strongly impacted by corruption on GDP per capita of 20 countries. 
DOI: $10.14807 /$ ijmp.v12i8.1470

He completed his study by using panel data ta approach that covers the period between 2003- 2011. Corruption has both negative and positive impacts on growth, which are captured in the paper of Dzhumashev (2009). He shows that corruptions have direct effects, at the same time, it also indirectly affects counts' economic situation. And this whole work is done by 141 countries from 2000-2007 time periods.

Monte and Papagni (2006), in their econometric data for Italy's 20regions from 1963 to 2001, tried to know the determinants of corruption. Swaleheen (2011) found corruption's has a significant direct impact on growth.

The main objective of Alfada (2019) was to estimate the corruption threshold by taking a nonlinear approach. His required data was from 19 provinces of Indonesia. By collecting data from the period of 2004 to 2015, he able to runs his analysis.

Aluchna et al.(2009) showed a negative impact of corruption on the economies and recommends strengthening accountability and bureaucratic quality. Anh et al. (2016) revealed negative relation between corruption and economic growth. Nwankwo (2014) showed Corruption negatively affects the economic growth of Nigeria and for faster economic growth in Nigeria zero tolerance in corruption is required. Also, recommend the anti-corruption agencies to stand strictly against corruption in Nigeria.

Aliyu and Elijah (2008) reveal the significant direct impact of corruption on economic growth and also should $20 \%$ of the government capital expenditure goes to private intersest. Ugur and Dasgupta, (2011) find corruption has an inverse association with per-capita GDP growth. Ndikumana, (2008) supports the view that corruption hampers economic growth and recommends improving the quality of governance. Corruption hampers economic growth in Pakistan but trade openness boosts economic growth is showed by Farooq et al. (2013). Monte and Papagni (2001) reveal the negative impact of corruption on growth in the case of Italy. Mo (2001) finds negative association between corruption growth.

Using EFI (Economic Freedom Index ) Ertimi et al. (2016) showed negative impact of corruption on economic growth and negative impact of corruption is also ensured by Nageri et al. (2013). Shao et al. (2007) observe a negative correlation between corruption growth.

Farida et al. (2008) showed that corruption deters growth and suggest that corruption boost inefficiencies in various sector.

Huang (2016) found positive causality between corruption to economic growth in South Korea. Brempong (2002) also showed negative association with corruption and the growth 
DOI: $10.14807 /$ ijmp.v12i8.1470

rates of GDP and per capita income. Anoruo and Braha (2005) reveal lower productivity, and restrict investment due to corruptions.

Grabova, (2014) also reveals negative association of corruption with economic growth. Egunjobi (2013) empirically investigates this topic in Nigeria and reveals that corruption exerts a negative influence on output of individual worker. Dridi (2013) also reveals inverse relation of corruption with growth.

Ghalwash, (2014) shows corruption is responsible for increased inefficiencies. Chamseddine (2016) finds a negative but statistically insignificant relationship between the observed countries' economic growth and the level of corruption. Berg and Schmidt (2006) found a positive relationship between trade and economic growth in Latin America. A long run co-integration is found among FDI, Trade Economic growth in Pakistan by Iqbal et al. (2010). Trade openness increases the initial per capita income in Brazilian states (Daumal, 2011).

Although there are enormous researches in this field, we are going to find the impact of corruption on these three countries as they are in the same geographical location. And also tries to find the impact of trade on economic growth in these countries.

\section{METHODOLOGY}

\section{Study Area}

For conducting the study, we have taken data from Bangladesh, India, and Pakistan to show the association between economic growth and corruption.

\section{Data collection and variables}

For this study necessary secondary data have been collected from 1990 to 2016 based on countries like Bangladesh, India, and Pakistan. Data for economic growth (dependent) and trade(independent) are collected from World Development Bank and data for corruption are taken from International Country Risk published by the PRS Group.

\section{Econometric model specification}

The panel data regression model for this study is given below in equation (1).

$$
G D P_{i t}=\beta_{0}+\beta_{1} \operatorname{Corrp}_{i t}+\beta_{2} T D_{i t}+\mu_{i t}
$$

Where i denotes countries and t denotes time.

$\mathrm{N}=$ Number of countries. 
$\mathrm{t}=$ Period

$\boldsymbol{\beta}_{0}, \boldsymbol{\beta}_{1}, \boldsymbol{\beta}_{2}$ are the parameters and $\boldsymbol{\mu}$ are error term. GDP= Gross domestic product per capita growth (annual \%), Corrp= Corruption, TD= Trade (\% of GDP growth).

\section{Fixed effect model}

Fixed effects (FE) model is applied to know the influence of variables which change over time( Adu-Gyamfi et al., 2019). FEM also recognized as “Least-Squares Dummy Variable (LSDV) model”. The value of intercepts changes for each cross section countries in this model(Raza et al., 2014). The equation for fixed effect model can be written as equation (2),

$Y_{i t}=\beta_{1} X_{i t}+a_{i}+\mu_{i t}$

Where, $\mathrm{Y}_{\mathrm{it}}$ is the dependent and $\mathrm{X}_{\mathrm{it}}$ independent variable and $\mu_{\mathrm{it}}$ is the error term.

\section{Random effect model}

Entities are assumed to be random and uncorrelated in random effect model (AduGyamfi et al., 2019). Basically in random effect model, units are taken randomly or from its population as representative (Tasci, 2009). The equation for random effect model can be written as equation (3),

$Y_{i t}=\beta_{1} X_{i t}+a_{i}+\mu_{i t}+\varepsilon_{i t}$

Where, $\mu_{\text {it }}$ is the between and $\varepsilon_{\text {it }}$ is the within-entity error.

\section{Panel ARDL Model}

Pesaran and Shin (1999) were the pioneer of the panel ARDL model and this model is expanded by Pesaran, Shin, and Smith (2001) which dealing with long and short-run association among the variables. The bounds testing approach is an important cointegration procedure compare to other procedures. Banerjee et al. (1993) showed that ECM can be derived from the ARDL approach whether the data is integrated at level or first difference or integrated in mixed order. Based on panel ARDL model we can write the equation for economic growth, corruption and trade,

$$
\begin{aligned}
\Delta G D P_{i t}=\beta_{i t} & +\beta_{1 i t} \operatorname{Corrp}_{i(t-1)}+\beta_{2 i t} T D_{i(t-1)}+\sum_{j=0}^{p} \beta_{3 i t} \operatorname{Corrp}_{i(t-1)}+\sum_{j=0}^{p} \beta_{4 i t} \beta_{1 i t} T D_{i(t-1)} \\
& +\Phi E C T_{i(t-1)}+\mu_{1 i t} \quad \ldots(4)
\end{aligned}
$$

Here, $\mu_{1 i t}$ is the error term, $\Delta$ refers first difference and $\Phi$ is the coefficient of ECT in the model. 
DOI: $10.14807 /$ ijmp.v12i8.1470

\section{HYPOTHESES STATEMENT}

\section{- H1: Corruption has a negative impact on economic growth}

Many studies identified the negative influence of corruption in various countries by many researchers such as Amin (2013), Pulok (2012), Egunjobi (2013), Aluchna et al. (2009), Dasgupta(2011) and Chamseddine(2016).

\section{- H2: Trade has a positive impact on economic growth}

Many studies have identified the positive influence of trade such as Azees et al. (2014), Kehindeet al. (2012) and Javedet al. (2012). They have found that trade accelarates the economic growth and development the domestic economy most of the cases that is why it is the most influential components.

\section{RESULTS AND DISCUSSION}

\section{Descriptive Statistics}

The descriptive statistics show 81 observations. Table 3 show that the mean value of GDPG is 3.455866; its standard deviation is 2.238356, and the maximum value and minimum value respectively 8.763184 and -1.449514 . The probability of Jarque-Bera shows that our data for Gross domestic product per capita growth, Corruption, Trade are normally distributed.

Table 3: Results of the Descriptive Statistics

\begin{tabular}{|c|c|c|c|}
\hline & GDP & Corrp & TD \\
\hline Mean & 3.455866 & 2.165123 & 33.72186 \\
\hline Median & 3.077798 & 2.000000 & 32.86893 \\
\hline Maximum & 8.763184 & 3.000000 & 55.79372 \\
\hline Minimum & -1.449514 & 0.083333 & 15.67452 \\
\hline Std. Dev & 2.238356 & 0.601447 & 9.529978 \\
\hline Skewness & 0.067968 & -0.470117 & 0.350619 \\
\hline Kurtosis & 2.569971 & 3.539322 & 2.585478 \\
\hline Jarque-Bera & 0.686487 & 3.965322 & 2.239529 \\
\hline Probability & 0.709465 & 0.137702 & 0.326357 \\
\hline Sum & 279.9252 & 175.3750 & 2731.470 \\
\hline Sum Sq. Dev. & 400.8190 & 28.93904 & 7265.638 \\
\hline Observations & 81 & 81 & 81 \\
\hline
\end{tabular}

\section{Panel Unit Root Test}

We have used panel unit root test to test the stationarity of the selected variables and and the result is presented in the Table 4 below and we see from the table that GDP per capita is integrated at $\mathrm{I}(0)$ level and corruption and trade are integrated at $\mathrm{I}(1)$ level indicates that our data is stationary at mixed order. 
INDEPENDENT JOURNAL OF MANAGEMENT \& PRODUCTION (IJM\&P)

http://www.ijmp.jor.br

v. 12, n. 8, November-December 2021

ISSN: 2236-269X

DOI: $10.14807 /$ ijmp.v12i8.1470

Table 4: Panel Unit Root Test

\begin{tabular}{|c|c|c|c|c|c|c|c|c|c|}
\hline \multirow{3}{*}{ Variables } & \multicolumn{4}{|c|}{ Levin, Lin \& Chut $t^{*}$} & \multicolumn{4}{|c|}{ Im, Pearson and Shin W-stat } & \multirow[t]{3}{*}{$\begin{array}{c}\text { Level of } \\
\text { integration }\end{array}$} \\
\hline & \multicolumn{2}{|c|}{ Level } & \multicolumn{2}{|c|}{ First Difference } & \multicolumn{2}{|c|}{ Level } & \multicolumn{2}{|c|}{ First Difference } & \\
\hline & t-stat & $P$-value & $T$ stat & $P$-value & $T$ stat & $P$-value & T stat & $P$-value & \\
\hline GDP Growth & -1.98946 & 0.0233 & -5.42735 & 0.0000 & -1.73985 & 0.0409 & -6.07811 & 0.0000 & $I(0)$ \\
\hline Corruption & -0.29378 & 0.3845 & -3.06494 & 0.0011 & -1.47202 & 0.0705 & -3.07304 & 0.0011 & I(1) \\
\hline Trade & -0.62516 & 0.2659 & -2.65458 & 0.0040 & 0.52418 & 0.6999 & -2.81551 & 0.0024 & I(1) \\
\hline
\end{tabular}

\section{Model Estimation}

We have 3 countries Bangladesh, India, and Pakistan. Three variables are growth rate, corruption, and trade. We want to check the relationship between GDP per capita and other two variables. We have a pooled, fixed, and random effect model. After estimating those models by using the Hausman test we able to find out which model is suitable. At first, we estimate the fixed-effect model; we can see that only trade has significant variables to explain growth. And then we check the random effect model, also here the trade is a significant variable because the probability value is very small and showed in Table 5.

Table 5: Fixed Effect Model and Random Effect Model

\begin{tabular}{|l|l|l|l|l|l|l|l|}
\hline \multicolumn{2}{|l|}{ Fixed effect model } \\
\hline Variable & Coefficient & Std. Error & Prob. & Variable & Coefficient & Std. Error & Prob. \\
\hline C & 0.495751 & 0.878502 & 0.5742 & C & -0.683943 & 0.840870 & 0.4185 \\
\hline CORRP & -0.074000 & 0.350933 & 0.8336 & CORRP & 0.572461 & 0.326653 & 0.0836 \\
\hline TD & 0.092532 & 0.020642 & 0.0000 & $T D$ & 0.086008 & 0.020615 & 0.0001 \\
\hline R-squared & 0.472971 & & R-square & 0.193353 & \\
Prob(F-statistic) & 0.000000 & & Prob(F-statistic) & 0.000229 & \\
Durbin-Watson stat & 1.576875 & & Durbin-Watson stat & 1.089437 & \\
\hline
\end{tabular}

Out of these two models, which one is the appropriate model for accepting. For this reason, we are going to check the Hausman test given in Table 6.

Table 6: Result of Hausman Test

\begin{tabular}{|l|l|l|l|}
\hline \multicolumn{5}{|c|}{ Hausman Test } \\
\hline Test Summary & Chi-Sq. Statistic & Chi-Sq. d.f & Prob. \\
\hline Cross-section random & 40.3221333 & 2 & 0.0000 \\
\hline
\end{tabular}

Here we can see from the Hausman Test that the probability value is less than $5 \%$, meaning that we can reject the null hypothesis and accepting alternative hypothesis. That means the fixed effect model is appropriate for our study. Here, trade is significant as the p-value is less than $5 \%$ but corruption value is not significant as the p-value is $83.36 \%$. So trade is a significant variable to explain our dependent variable. Where 1unit increase in corruption decreases GDP by 0.07 units and shows a negative relationship with GDP. Again if trade increases by 1 unit then GDP will increase by 0.09 units on average and shows a positive relationship. 
INDEPENDENT JOURNAL OF MANAGEMENT \& PRODUCTION (IJM\&P)

http://www.ijmp.jor.br

v. 12, n. 8, November-December 2021

ISSN: 2236-269X

DOI: $10.14807 /$ ijmp.v12i8.1470

From the unit root test, we can see that all our variables are integrated into the mixed order. So apply here ARDL procedure for long and short-run impact of corruption on growth in these three countries.

\section{Optimal Lag Selection}

Table 7 shows optimal lags is 1 for the ARDL model.

Table 7: Lags Length Selection

\begin{tabular}{lllllll}
\hline Lag & LogL & LR & FPE & AIC & SC & HQ \\
\hline \hline 0 & -427.4562 & NA & 92.80531 & 13.04413 & 13.14366 & 13.08346 \\
1 & -292.9875 & 252.6382 & $2.072717^{*}$ & $9.242045^{*}$ & $9.640164 *$ & $9.399361^{*}$ \\
2 & -286.5815 & 11.45314 & 2.246611 & 9.320652 & 10.01736 & 9.595954 \\
3 & -281.9679 & 7.829189 & 2.577951 & 9.453572 & 10.44887 & 9.846861 \\
4 & -274.8266 & 11.46935 & 2.750864 & 9.509897 & 10.80378 & 10.02117 \\
5 & -262.8202 & $18.19152 *$ & 2.546463 & 9.418793 & 11.01127 & 10.04806 \\
\hline \hline
\end{tabular}

\section{Estimates of Panel ARDL Model}

Table 8 shows result of panel ARDL model. We find that the coefficient of corruption is positive but not significant which means it has a long-run positive impact on economic growth by $3 \%$ but trade has a long-run positive impact on economic growth in these three countries and significant at a $1 \%$ level of significance and reveals that $1 \%$ increase in trade will lead $12 \%$ increase in economic growth. The error correction term indicating that the adjustment is corrected by $70 \%$ in these three countries.

Table 8: Long Term and Short Term Coefficients

\begin{tabular}{|c|c|c|c|c|}
\hline \multicolumn{2}{|c|}{ Variable } & Coefficients & T statistics & Probability \\
\hline Long- Run & Corrp & 0.039404 & 0.130320 & 0.8967 \\
\cline { 2 - 5 } & TD & 0.125473 & 5.556575 & 0.0000 \\
\hline Short-Run & ECM & -0.702180 & -4.842383 & 0.0000 \\
\cline { 2 - 5 } & $\Delta$ Corrp & -0.425724 & -0.406044 & 0.6860 \\
\cline { 2 - 5 } & $\Delta T D$ & -0.076045 & -1.371765 & 0.1747 \\
\cline { 2 - 5 } & C & -0.368185 & -0.858746 & 0.3935 \\
\hline
\end{tabular}

\section{Findings}

From the fixed-effect model we noticed that corruption is negatively associated with GDP growth in these three countries which result is also supported by the study of Aluchna et al. (2009), Anh et al. (2016), Nwankwo (2014) and Ugur and Dasgupta (2011). But the coefficient is not statistically significant. Again, trade is significantly and positively associated with GDP growth in these three countries which result is also supported by the study Azees et al. (2014), Kehinde et al. (2012) and Javed et al. (2012). From the Panel ARDL model, it finds that corruption positively but not significantly impacts growth but trade significantly and positively impacts growth and reveals that if trade increases by $1 \%$ than growth will increase 
DOI: 10.14807/ijmp.v12i8.1470

by $12 \%$ on average.

\section{CONCLUSION AND POLICY RECOMMENDATIONS}

The main motive of the paper is to know the impact of corruption on growth in Bangladesh, India, and Pakistan during 1990-2016. For investigating empirically the existence of a long-run or short-run association between corruption and growth, we used ECM ARDL Model and the Fixed Effect Model.We used panel unit root test and found that GDP is stationary at $\mathrm{I}(0)$ and corruption and trade is stationary at $\mathrm{I}(1)$.

The Houseman test ensures that the fixed effect model is appropriate. Here, trade is significant as the p-value is less than $5 \%$ but corruption value is not significant as the p-value is $\mathbf{8 3 . 3 6 \%}$. So trade is a significant variable to explain our dependent variable. Where 1unit increases in corruption decrease GDP by 0.07 units and show a negative relationship with GDP. Again if trade increases by 1 unit then GDP will increase by 0.09 units on average and shows a positive relationship.

From the panel ARDL model, we find that the positive coefficient of corruption means it has a long-run positive impact on growth but it's not statistically significant but long run impact of trade is significant impact on economic growth in these three countries. The error correction term indicating that the adjustment is corrected by $70 \%$ in these three countries.

Based on the result of the study we can recommend the following policy. Any countries economics are unable to function and operate their activities properly because corruption prevents the as usual laws of the economy from functioning freely. Corruption has direct and indirect effects of these variables on growth. Corruption has an indirect impact on trade. Other countries don't want to trade with the high corrupted country. And we all know that trade is one of the major contributors to the growth of the country. The government of these countries should take proper measures to combat corruption from all the economic sectors as corruption hinders economic growth.

\section{REFERENCES}

Adu-Gyamfi, G., Nketiah, E., Obuobi, B., \& Adjei, M., (2019). Trade Openness, Inflation and GDP Growth: Panel Data Evidence from Nine (9). West Africa Countries. Open Journal of Business and Management, 8(1),314-328.

Alfada, A. (2019). The destructive effect of corruption on economic growth in Indonesia: A threshold model. Heliyon, 5(10), 1-14. Avaliable:

https://www.ncbi.nlm.nih.gov/pmc/articles/PMC6838995/ 
Aliyu, S. U. R., \& Elijah, A. O. (2008). Corruption and economic growth in Nigeria: 19862007. MPRA, 1-20. Avaliable: https://mpra.ub.unimuenchen.de/12504/1/MPRA_paper_12504.

Aluchna, M., Mobolaji, H. I., \& Omoteso, K. (2009). Corruption and economic growth in some selected transitional economies. Social Responsibility Journal, 5(1), 70-82. DOI: 10.1108/17471110910940014.

Amin, M., Ahmed, A., \& Zaman, K. (2013). The relationship between corruption and economic growth in Pakistan - looking beyond the incumbent. Economics of Knowledge, 5(3), 16-45.

Anh, N. N., Minh, N. N., \& Tran-Nam, B. (2016). Corruption and economic growth, with a focus on Vietnam. Crime, Law, and Social Change, 65(4-5), 307-324.

Anoruo, E., \& Braha, H. (2005). Corruption and economic growth: the African experience. Journal of Sustainable Development in Africa, 7(1), 43-55.

Kehinde, A. O., Jubril, A. O., \& Felix, A. O. (2012). Foreign trade and economic growth in Nigeria: An empirical analysis. American Academic \& Scholarly Research Journal, 4(5), $1-12$.

Azeez, B. A., Dada, S. O., \& Aluko, O. A. (2014). Effect of international trade on Nigerian economic growth: The 21st century experience. International Journal of Economics, Commerce and Management, 2(10), 1-8.

Banerjee, A., Dolado, J. J., Galbraith, J. W., \& Hendry D. F. (1993). Co-integration, Error Correction, and the Econometric Analysis of Non-stationary Data. Oxford University Press, Oxford.

Berg, H. V. D., \& Schmidt, J. R. (1994). Foreign trade and economic growth: time series evidence from Latin America. Journal of International Trade \& Economic Development, 3(3), 249-268. DOI: 10.1080/09638199400000016.

Chamseddine, N. (2016). Corruption and Economic Growth in the Middle East and North Africa. Bachelor of Science Thesis, Department of Economics, Trinity College.

Craigwell, R., \& Wright, A. (2011). Foreign direct investment and corruption in developing economies: Evidence from linear and non-linear panel Granger causality tests. Economics

Bulletin, 31(3), 2272-2283.

Daumal, M. (2010). The impact of international trade flows on economic growth in Brazilian states. Review of Economics and Institutions, 2(1), 1-25.

Del Monte, A., \& Papagni, E. (2001). Public expenditure, corruption, and economic growth: the case of Italy. European journal of political economy, 17(1), 1-16. DOI: 10.5202

Dridi, M. (2013). Corruption and economic growth: the transmission channels. MRPA, 121152. Avaliable: https://mpra.ub.uni-muenchen.de/47873/1/MPRA_paper_47873.pdf

Dzhumashev, R. (2009). Is there a direct effect of corruption on growth? Munich Personal RePEc Archive, 1-16.

Egunjobi, T. A. (2013). An econometric analysis of the impact of Corruption on economic growth in Nigeria. E3 Journal of Business Management and Economics, 4(3), 054-065.

Ertimi, B. E., Dowa, A., Albisht E. M., \& Oqab, B. A. (2016). The impact of corruption on economic growth in OIC countries. International Journal of Economics and Finance, 8(9), 91-103. 
Farida, M., \& Ahmadi-Esfahani, F. Z. (2008). Corruption and economic growth in Lebanon. Avaliable: Conference (52nd)., February 5-8, 2008, Canberra, Australia 6043, Australian Agricultural and Resource Economics Society, 1-27.

https://ideas.repec.org/p/ags/aare08/6043.html. DOI: 10.22004/ag.econ.6043

Farooq, A., Shahbaz, M., Arouri, M., \& Teulon, F. (2013). Does corruption impede economic growth in Pakistan?. Economic Modelling, 35, 622-633. DOI:

10.1016/j.econmod.2013.08.019.

Ghalwash, T. (2014). Corruption and economic growth: Evidence from Egypt. Modern Economy, 5(10), 1001-1009.

Grabova, P. (2014). Corruption impact on Economic Growth: An empirical analysis. Journal of Economic Development, Management, IT, Finance, and Marketing, 6( 2), 57.

Gyimah-Brempong, K., \& Gyimah-Brempong, S. M. (2006). Corruption, growth, and income distribution: Are their regional differences?. Economics of Governance,7(3), 245269.

Huang, C. J. (2016). Is corruption bad for economic growth? Evidence from Asia-Pacific countries. The North American Journal of Economics and Finance, 35, 247-256. DOI: 10.1016/j.najef.2015.10.013.

Iftekharuzzaman (2011). Bangladesh at 40: Changes and Challenges. Seminar Paper presented in theFaculty of Business Studies, Janhangirnagar, University, Dhaka, Bangladesh. Avaliable: https://www.ti-bangladesh.org/research/JNU-pap-rev.pdf

Iqbal, M. S., Shaikh, F. M., \& Shar, A. H. (2010). Causality relationship between foreign direct investment, trade, and economic growth in Pakistan. Asian Social Science, 6(9), 82.

Javed, Z. H., Qaiser, I., Mushtaq, A., \& Iqbal, A. (2012). Effects of international trade on economic growth: The case study of Pakistan. International Journal of Academic Research in Progressive Education and Development, 1(2), 103-113.

Max Roser (2013). Economic Growth. Published online at OurWorldInData.org.

Taghavi, H. N. M. (2011). Comparing Impact of Administrative Corruption on Economic Growth in Developing Countries. Int. J. Manag. Bus. Res., 1(2), 93-98.

Mo, P. H. (2001). Corruption and economic growth. Journal of comparative economics, 29(1), 66-79.DOI: 10.1006/jсес.2000.1703.

Mustapha, N. (2014). The impact of corruption on GDP per capita. Journal of Eastern European and Central Asian Research, 1(2), 1-5. DOI: 10.15549/jeecar.v1i2.76 .

Nageri, K. I., Umar, G., \& Abdul, F. A. (2013). Corruption and economic development: Evidence from Nigeria. Kuwait Chapter of the Arabian Journal of Business and Management Review, 3(2), 46.

Ndikumana, L., \& Baliamoune-Lutz, M. (2008). Corruption and growth: Exploring the investment channel (No. 2008-08). The University of Massachusetts Amherst, Department of Economics.

Thach, N. N., Duong, M. B., \& Oanh, T. T. K. (2017). Effects of Corruption on Economic Growth -Empirical Study of Asia Countries. Imperial Journal of Interdisciplinary Research(IJIR),3(4), 791-804.

Nwankwo, O. F. (2014). Impact of corruption on economic growth in Nigeria.

Mediterranean Journal of Social Sciences, 5(6), 41. DOI: 10.5901/mjss.2014.v5n6p41. 
Pesaran, M. H., Shin, Y., \& Smith, R. J. (2001). Bounds testing approaches to the analysis of level relationships. Journal of Applied Econometrics, 16(3), 289-326. DOI: 10.1002/jae.616.

Pesaran., M. H., \& Shin, Y. (1999). An autoregressive distributed lag modeling approach to cointegration analysis. In Strom, S. (ed.)., Econometrics and Economic Theory in the 20th Century: The Ragnar Frisch Centennial Symposium. Chapter 11. Cambridge: Cambridge University Press.

Pulok, M. H. (2012). The Impact of Corruption on Economic Development of

Bangladesh: Evidence on the Basis of an Extended Solow Model. Department of Economics, Stockhum University, 1-43.

Raza, S. H., Shahzadi, H., \& Akram, M. (2014). Exploring the determinants of financial development (using panel data on developed and developing countries). Journal of finance and economics, 2(5),166-172.

Shao, J., Ivanov, P. C., Podobnik, B., \& Stanley, H. E. (2007). Quantitative relations between corruption and economic factors. The European physical journal B, 56(2), 157-166.

Swaleheen, M. (2011). Economic growth with endogenous corruption: an empirical study. Public Choice, 146(1-2), 23-41.

Tasci, M., Esener, S. Ç., \& Darici, B. (2009). The effects of openness on inflation: panel data estimates from selected developing countries. Investment management and financial Innovations, 6(4), 28-34.

Thach, N. N., Duong, M. B., \&Oanh, T. T. K. (2017). Effects of corruption on the economic growth-empirical study of Asia countries. Imperial Journal of Interdisciplinary Research, 7), 791-804.

Tomola M., \& Obamuyi, S. O. (2019). Corruption and economic growth in India and Nigeria. Journal of Economics and Management, 35(1), 80-105.

Ugur, M., Dasgupta, N. (2011). Corruption and economic growth: A meta-analysis of the evidence on low-income countries and beyond. MPRA Paper No 31226, 1-45. Avaliable: file://C:/Users/user/Downloads/MPRA_paper_31226_Nandini_MU.pdf

WDI (2017). World Development Indicators, World Bank, Washington DC, Avaliable: https://data.worldbank.org/

World Bank Group (2020). The Worldwide Governance Indicators (WGI). Avaliable: https://info.worldbank.org/governance/wgi/. 